KS. BP HENRYK TOMASIK

\title{
ŚWIATOWE DNI MŁODZIEŻY JAKO WYDARZENIE KATECHETYCZNE ${ }^{1}$
}

Światowe Dni Młodzieży „zrodziły się” podczas spotkań Ojca Świętego Jana Pawła II z młodymi. Szczególne znaczenie miały spotkania w Rzymie, w ramach Nadzwyczajnego Jubileuszu Odkupienia, w dniach 11-15 kwietnia 1984 r. W Niedzielę Palmową, 15 kwietnia 1984 r., Ojciec Święty mówił do młodych: „w entuzjazmie pielgrzymów, zdążających do Jerozolimy wraz z Chrystusem, szczególny udział mieli młodzi: dzieci i młodzież. Pueri Hebreorum. Tym tłumaczy się także szczególny udział młodych w liturgii Niedzieli Palmowej na placu Św. Piotra. Tak jest co roku. Ale tak jest szczególnie w bieżącym Roku Odkupienia, kiedy Niedziela Palmowa stała się centrum nadzwyczajnego Jubileuszu młodzieży. (...) Młodzi więc otaczają Jezusa Chrystusa w liturgii Niedzieli Palmowej, aby wyrazić ten entuzjazm, jaki wywołuje Jego Osoba w coraz to nowych pokoleniach"2.

Tydzień później, w Niedzielę Wielkanocną 22 kwietnia 1984 r., na zakończenie Roku Świętego Ojciec Święty przekazał młodzieży Krzyż Roku Jubileuszowego. Jan Paweł II powiedział wówczas: „Umiłowani młodzi, u kresu Roku Świętego powierzam wam znak tego Roku Jubileuszowego: Krzyż Chrystusa. Ponieście go na cały świat jako znak miłości, którą Pan Jezus umiłował ludzkość i głoście wszystkim, że tylko w Chrystusie umarłym i zmartwychwstałym jest ratunek i odkupienie".

Rok 1985 został ogłoszony przez Organizację Narodów Zjednoczonych jako Międzynarodowy Rok Młodzieży. W Niedzielę Palmową tego roku Ojciec Święty przekazał młodym specjalny list. W Liście tym Jan Paweł II napisał: „Tak więc, młodzi Przyjaciele, oddaję w Wasze ręce ten List, który znajduje się na przedłużeniu ewangelicznej rozmowy Chrystusa z młodzieńcem i wyrasta ze świadectwa Apostołów i pierwszych pokoleń chrześcijan. Oddaję Wam ten List w „Roku Młodzieży”, gdy przybliżamy się do kresu drugiego tysiąclecia. (...) Czynię to w Niedzielę Palmową - w dniu, w którym dane mi jest spotkać się z wieloma wśród Was jako pielgrzymami na placu Świętego Piotra w Rzymie. W tym właśnie

1 Niniejszy artykuł powstał na kanwie wypowiedzi w panelu dyskusyjnym podczas Sympozjum Stowarzyszenia Katechetyków Polskich (23-24.09.2014) w Częstochowie.

2 Jan Paweł II, L'OsRomPol 4(1984), s. 1. 
dniu Biskup Rzymu modli się wspólnie z Wami za wszystkich Młodych na całym świecie, za każdą i za każdego"”.

W wygłoszonym tydzień później Orędziu Wielkanocnym (7 kwietnia 1985 r.), Ojciec Swięty wspomniał fakt przekazania Listu do Młodych i - co jest bardzo ważne - po raz pierwszy zapowiedział Światowe Dni Młodzieży: „Z tysiącami młodych spotkałem się w ubiegłą niedzielę i pozostał w mej duszy świąteczny obraz ich entuzjazmu. Życząc, aby to wspaniałe przeżycie mogło powtórzyć się w przyszłych latach, i dać początek Światowemu Dniowi Młodzieży w Niedzielę Palmową"4.

Do tej zapowiedzi oraz spotkania z młodzieżą w Niedzielę Palmową nawiązał Ojciec Święty w dniu 20 grudnia 1985 r. podczas spotkania opłatkowego, w którym uczestniczyło Kolegium Kardynałów oraz pracownicy Kurii Rzymskiej: Pan pobłogosławił temu spotkaniu w sposób szczególny, bowiem od tamtej pory Światowy Dzień Młodzieży będzie obchodzony co roku w Niedziele Palmowa, przy wydatnej wspótpracy Rady Świeckich ${ }^{5}$. Tę datę, 20 grudnia 1985 r., uznaje się jako dzień ustanowienia Światowych Dni Młodzieży.

Pierwszy „numerowany” Światowy Dzień Młodzieży był przeżywany w Niedzielę Palmową, 23 marca 1986 r., w Rzymie oraz w diecezjach całego Kościoła. Do Rzymu przybyła młodzież włoska oraz reprezentacja wielu krajów. W homilii Ojciec Święty Jan Paweł II mówił: Dziś jesteście tutaj znowu, drodzy młodzi przyjaciele, aby w Rzymie, na placu św. Piotra, zapoczątkować tradycję Dnia Młodzieży, do którego został wezwany cały Kościót (...) Punktem odniesienia tego dnia pozostaje w każdym roku Niedziela Palmowa (...) To właśnie znaczy „Dzień Młodzieży”: wyjście na spotkanie Boga, który wszedł w dzieje człowieka poprzez tajemnice paschalna Jezusa Chrystusa ${ }^{6}$.

\section{Cztery dynamizmy Światowych Dni Młodzieży}

Na fenomen Światowych Dni Młodzieży szczególny wpływ mają cztery dynamizmy, które potrafił św. Jan Paweł II dostrzec w ludziach młodych i je uruchomić. Są nimi:

- chrystocentryzm (młodzi tak naprawdę szukają Chrystusa w swoim życiu i chcą go spotkać)

- entuzjazm (młodzi chcą się spotykać i wspólnie manifestować swoją wiarę)

- kontemplacja krzyża (skupienie wokół krzyża jako znaku Odkupienia otwiera młodych na głębokie doświadczenia duchowe i wzbudza ducha ofiary)

\footnotetext{
3 Jan Paweł II, List do młodych całego świata, nr 16, http://www.opoka.org.pl/biblioteka/W/WP/ jan_pawel_ii/listy/parati.html\#

4 Tenże, Orędzie Wielkanocne, L’OsRomPol 4-5(1985), s. 12.

5 Jan Paweł II, Przemówienie do Kurii Rzymskiej, 20 grudnia 1985 roku, L'OsRomPol 1(1981), s.12

6 Tenże, Niedziela Palmowa. Homilia, L'OsRomPol 3(1986), s.6.
} 
- afirmacja młodości (młodość jest wartością, tkwi w niej wielki potencjał, który młodzi chcą w sobie uruchomiać).

Każdy z wymienionych dynamizmów ma znaczący wpływ na ostateczny kształt wydarzenia, jakim są Światowe Dni Młodzieży. Ich wykorzystanie w duszpasterstwie młodzieżowym będzie przyczyniało się do tego, że doświadczenie wielkiego spotkania młodych $\mathrm{z}$ akcji przekształci się w formację katechetyczną.

\section{Chrystocentryzm}

Światowe Dni Młodzieży są uroczystym potwierdzeniem „tak” Chrystusowi. Są także wyjątkową okazją do odnowienia decyzji opowiadania się za Chrystusem: W świetle powierzonego nam przez Chrystusa misyjnego zadania widać wyraźnie sens i znaczenie Światowych Dni Młodzieży, organizowanych w Kościele. Uczestniczac w tych spotkaniach, młodzi pragna potwierdzić i odnowić ich "tak” powiedziane Chrystusowi i Jego Kościołowi, powtarzając za Izajaszem: „Oto ja, poślij mnie!” (Iz 6, 8) - dodaje Ojciec Święty w Orędziu na VII Światowy Dzień Młodzieży.

Ojciec Święty Jan Paweł II, w Liście skierowanym do kard. Eduardo Pironio z okazji seminarium zorganizowanego w dniach 13-16 maja 1996 roku, w Częstochowie, przez Papieską Radę ds. Świeckich, w bardzo ciekawy sposób mówił o znaczeniu Światowych Dni Młodzieży: Przede wszystkim musimy podziękować Bogu za obfite i różnorodne owoce, jakie przynosza Światowe Dni Młodzieży. Od pierwszego spotkania na placu św. Piotra w Niedzielę Palmowa 1986 r. ukształtowała się tradycja, $w$ ramach której $w$ kolejnych latach odbywaja się na zmianę spotkania światowe lub diecezjalne, co jest poniekąd symbolem swoistej dynamiki apostolstwa młodych, które winno się rozwijać w wymiarze lokalnym i powszechnym ${ }^{8}$.

Celem Światowych Dni Młodzieży jest wspólnotowe wyznanie wiary w Jezusa Chrystusa: Zasadniczym celem Dni jest skupienie wiary i życia każdego młodego człowieka wokół osoby Jezusa, tak aby On stał się trwałym punktem odniesienia oraz prawdziwym światłem dla każdej inicjatywy i dla wszelkich działań wychowawczych wśród nowych pokoleń. Taki jest «refren» każdego Światowego Dnia. Wszystkie zaś razem Dni Młodzieży obchodzone w minionym dziesięcioleciu jawia sie jako nieustanne, naglace wezwanie do budowania życia i wiary na skale, która jest Chrystus - dodał Ojciec Święty w tymże Liście.

\section{Entuzjazm młodości}

Światowe Dni Młodzieży - stwierdzał św. Jan Paweł II - stały się wielkim i fascynującym świadectwem, jakie młodzież daje o sobie, stały się potężnym środkiem ewangelizacji. Jest bowiem $w$ młodych ludziach olbrzymi potencjał dobra i twórczych możliwości. Ilekroć znajduję się na spotkaniach z młodymi w jakimkolwiek

\footnotetext{
7 Jan Paweł II, Orędzie na VII ŚDM, 1992, L’OsRomPol 2(1992)

8 List Ojca Świętego do kard. E. F. Pironio z okazji seminarium zorganizowanego w dniach 13-16 maja 1996 r. w Częstochowie, L’OsRomPol 7-8(1996)s. 4, p. 1
} 
miejscu świata, czekam przede wszystkim na to, co oni zechcą mi powiedzieć o sobie, o swoim społeczeństwie, o swoim Kościele. I zawsze im to uświadamiam. „Nie jest wcale najważniejsze, co ja wam powiem - ważne jest to, co wy mi powiecie. Powiecie niekoniecznie słowami, powiecie waszą obecnością, waszym śpiewem, może nawet waszym tańcem, waszymi inscenizacjami, wreszcie waszym entuzjazmem".

Potrzeba nam - kontynuował Jan Paweł II - tego młodzieżowego entuzjazmu. Potrzeba nam tej radości życia, którą mają młodzi. W tej radości życia jest coś $z$ tej pierwotnej radości, jaką miał Bóg stwarzając człowieka. Młodzi mają w sobie właśnie tę radość. Jest ona $w$ każdym miejscu ta sama, a równocześnie inna, oryginalna. Potrafią ją po swojemu wypowiedzieć. To wcale nie jest tak, że Papież prowadzi młodych z jednego krańca globu ziemskiego na drugi. To oni go prowadzą. I choć mu przybywa lat, każą mu być młodym, nie pozwalają mu zapomnieć o jego własnym doświadczeniu, o jego własnym odkryciu młodości i jej wielkiego znaczenia dla życia każdego człowieka. Myślę, że to wiele tłumaczy.

\section{Przyjęcie znaku krzyża}

Młodzież skupiona ośrodku Centrum San Lorenzo w Rzymie włączyła się w uroczystość otwarcia Jubileuszowego Roku Odkupienia w dniu 25 marca 1983 r. Tego dnia Ojciec Święty Jan Paweł II przybył do kościoła Sancti Stephani Aetiopum znajdującego się w Ogrodach Watykańskich. Przy tej starożytnej świątyni oczekiwali na Papieża kardynałowie, biskupi, kapłani oraz alumni. Przybyła także młodzież z Młodzież przyniosła prosty, drewniany, duży Krzyż (o wymiarach: 380 cm x $175 \mathrm{~cm}$ ). Został on włączony do procesji pokutnej, której przewodniczył Ojciec Święty wspierając się na tradycyjnym pastorale patriarszym zwanym ferula (ma kształt potrójnego krzyża). W procesji młodzież z Centrum San Lorenzo niosła wspomniany Krzyż.

Procesja przeszła przez plac św. Piotra i zatrzymała się w atrium Bazyliki św. Piotra. Gdy Jan Paweł II podszedł do Drzwi Świętych, uderzył je trzy razy ozdobnym młotkiem i, wypowiadając słowa: Otwórzcie drzwi sprawiedliwości, dokonał otwarcia Roku Świętego. Po otwarciu Drzwi Świętych Ojciec Święty przeszedł przez nie, jako pierwszy pielgrzym. Tuż za Papieżem, przez Drzwi Święte przeszła młodzież z dużym drewnianym Krzyżem.

Krzyż ten został następnie ustawiony obok konfesji św. Piotra i stał się znakiem Nadzwyczajnego Jubileuszu Odkupienia. Przebywał tu 394 dni, aż do zakończenia Roku Świętego w Niedzielę Wielkanocną 22 kwietnia 1984 r. Ojciec Święty dokonał wówczas zamknięcia Drzwi Świętych. Zaraz po tej ceremonii, w atrium Bazyliki św. Piotra, Jan Paweł II przekazał Krzyż Roku Świętego młodzieży i powiedział: Umiłowani młodzi, u kresu Roku Świętego powierzam wam znak tego Roku Jubileuszowego: Krzyż Chrystusa. Ponieście Go na cały świat jako znak miłości, która 
Pan Jezus umiłował ludzkość i głoście wszystkim, że tylko w Chrystusie umarłym i zmartwychwstałym jest ratunek i odkupienie 9 .

Krzyż Roku Świętego, przekazany młodzieży przez Ojca Świętego Jana Pawła II na zakończenie Wielkiego Jubileuszu Odkupienia w dniu 22 kwietnia 1984 r. stał się Krzyżem Młodych, Krzyżem Pielgrzymującym, a po pewnym czasie otrzymał tytuł: Krzyż Światowych Dni Młodzieży. Na Jasnej Górze, podczas Czuwania Modlitewnego 14 sierpnia 1991 r., Jan Paweł II powiedział: Pośrodku naszego czuwania stanął krzyż. Wnieśliście ten krzyż i ustawiliście $w$ środku. W tym krzyżu objawiło się do końca Boskie "Jestem» nowego i wiecznego Przymierza. «Tak (...) Bóg umiłowat świat, że Syna swego Jednorodzonego dał, aby [człowiek] nie zginat, ale miat życie wieczne" (J 3,16)». Krzyż - zapis tej niepojętej miłości. Krzyż - znak objawiający, że «Bóg jest miłością» $(1 \mathrm{~J} \mathrm{4,8})^{10}$.

W Orędziu na XV Światowy Dzień Młodzieży - był to rok 2000 - Jan Paweł II przypomniał: Piętnaście lat temu, na zakończenie Świętego Roku Odkupienia, powierzyłem wam wielki drewniany krzyż, zachęcając was, byście nieśli go przez świat jako znak miłości Pana Jezusa do ludzi i jako orędzie, że zbawienie i odkupienie jest tylko w Chrystusie, który umarł i zmartwychwstał. Od tamtego czasu, gdy podjęty go wasze ofiarne ramiona i serca, odbywa on długa i nieprzerwana pielgrzymke przez kontynenty, ukazując, że krzyż idzie z młodymi, a młodzi ida z krzyżem. Wokół "krzyża Roku Świętego» narodziła się i rozwinęła inicjatywa Światowych Dni Młodzieży ${ }^{11}$.

Niezwykle wzruszające były osobiste spotkania Ojca Świętego Jana Pawła II z Krzyżem. Także z krzyżem własnego cierpienia. W dniu 20 marca 2005 r. Ojciec Święty nie mógł przewodniczyć uroczystościom Niedzieli Palmowej. Uczynił to w imieniu Ojca Świętego kard. Carlo Ruini, wikariusz Papieża dla diecezji rzymskiej. Przed Modlitwą Anioł Pański abp Leonardo Sandri odczytał rozważanie Ojca Świętego, który pisał: Przed dwudziestu laty na tym właśnie Placu zostały zainaugurowane Światowe Dni Młodzieży. Dlatego dziś w sposób szczególny zwracam się do młodych. (...) Adorujecie dziś krzyż Chrystusa, który niesiecie przez cały świat ponieważ uwierzyliście miłości Boga, która w pełni ujawniła się w Chrystusie Ukrzyżowanym. (...) Dzisiaj mówię Wam: idźcie dalej niestrudzenie wybraną droga, abyście $w$ każdym miejscu byli świadkami chwalebnego Krzyża Chrystusa. Nie lękajcie się! Niech radość ukrzyżowanego i zmartwychwstałego Pana będzie wasza siła, a Przenajświętsza Maryja Panna niech zawsze wam towarzyszy ${ }^{12}$.

Podobnie o znaczeniu krzyża dla idei Światowych Dni Młodzieży wypowiadał się papież Benedykt XVI. Ojciec Święty podczas spotkania z kardynałami i pracownikami Kurii Rzymskiej w dniu 22 grudnia 2008 r., dokonał podsumowania

\footnotetext{
9 Tenże, L’OsRomPol 4(1984), s. 1.

10 Tenże, L’OsRomPol 8(1991), s. 22.

11 Tenże, Orędzie na XV Światowy Dzień Młodzieży, p.1

12 Tenże, L'OsRomPol 5(2005), s. 38.
} 
ks. bp Henryk Tomasik

najważniejszych wydarzeń kończącego się roku. Znaczna część przemówienia była poświęcona Światowym Dniom Młodzieży oraz modlitwie przy Krzyżu. Mówił wówczas Papież: To publiczne pokazywanie się wiary porusza wszystkich, którzy staraja się zrozumieć obecne czasy $i$ działajace $w$ nich siły. Zwłaszcza fenomen Światowych Dni Młodzieży staje się coraz częściej przedmiotem analiz, w których próbuje się zrozumieć ten rodzaj - jeśli tak można się wyrazić - kultury młodzieżowej. (...) Było to święto radości - radości, która w końcu udzieliła się także niechętnym.

(...) Trzeba przede wszystkim mieć na uwadze to, że Światowe Dni Młodzieży nie ograniczaja się do tego jednego tygodnia, w którym staja się widzialne dla świata. Prowadzi do nich dluga droga zewnętrzna i wewnętrzna. Krzyż, któremu towarzyszy obraz Matki Pana, pielgrzymuje przez kraje. Wiara, na swój sposób, potrzebuje widzieć i dotykać. Spotkanie z krzyżem, którego się dotyka jest niekiedy wewnętrznym spotkaniem z Tym, który umarł za nas na krzyżu. Spotkanie z krzyżem budzi $w$ młodych ludziach pamięć o tym Bogu, który zechciał stać się człowiekiem i z nami cierpieć. I widzimy Niewiastę, która On nam dał za Matkę. Uroczyste dni są tylko zwieńczeniem długiej drogi, na której ludzie spotykaja się ze soba i razem ida na spotkanie z Chrystusem ${ }^{13}$.

\section{Afirmacja młodości}

Vittorio Messori przeprowadził bardzo ciekawy wywiad z Ojcem Świętym Janem Pawłem II. Podczas tego wywiadu Święty Jan Paweł II powiedział: Każdy proboszcz w Rzymie wie, że odwiedziny w parafi musi zakończyć spotkaniem Biskupa Rzymu z młodzieżą. I nie tylko w Rzymie, ale także gdziekolwiek Papież się pojawi, „wszędzie szuka młodzieży i wszędzie jest przez tę młodzież szukany. Ale właściwie to nie on jest szukany! To jest szukany Chrystus”, który wie, „,o w człowieku się kryje”" (J 2, 25), zwłaszcza w młodym człowieku, i daje na jego pytania prawdziwe odpowiedzi! A jeśli to bywają odpowiedzi wymagające, młodzież wcale od nich nie stroni, owszem, na nie oczekuje.

Geneza Światowych Dni Młodzieży - mówił dalej Ojciec Święty - również tym się tłumaczy. Najpierw przy okazji Jubileuszowego Roku Odkupienia, a potem w związku z Międzynarodowym Rokiem Młodzieży, ogłoszonym przez ONZ (1985), młodzi zostali zaproszeni do Rzymu. I to był początek. Nikt nie wymyślił Światowych Dni Młodzieży. Oni sami je stworzyli. Takie Dni, takie spotkania stały się odtąd potrzebą młodzieży na wszystkich miejscach świata. Niejednokrotnie są one dla duszpasterzy, a także dla Biskupów wielkim zaskoczeniem. Przerastają to, czego oni sami oczekiwali ${ }^{14}$.

13 Tenże, L’OsRomPol 2(2009), s. 10.

14 Tenże, Przekroczyć próg nadziei, Lublin, 1994, s. 103 - 105. 


\section{Wyzwania i zadania „eklezjologii” Światowych Dni Młodzieży}

W Liście skierowanym do kard. Eduardo Pironio z okazji seminarium zorganizowanego w dniach 13-16 maja 1996 roku, w Częstochowie, przez Papieską Radę ds. Świeckich, Ojciec Święty tak napisał o znaczeniu Światowych Dni Młodzieży: Przede wszystkim musimy podziękować Bogu za obfite i różnorodne owoce, jakie przynosza Światowe Dni Młodzieży. Od pierwszego spotkania na placu św. Piotra $w$ Niedzielę Palmowa 1986 r. ukształtowała się tradycja, w ramach której w kolejnych odbywaja się na zmiane spotkania światowe lub diecezjalne, co jest poniekad symbolem swoistej dynamiki apostolstwa młodych, które winno się rozwijać w wymiarze lokalnym i powszechnym ${ }^{15}$.

W dniu inauguracji Pontyfikatu, 22 października 1978 roku, już po zakończeniu liturgii - dodał Jan Paweł II - powiedziałem do młodych ludzi na Placu św. Piotra: ,Wy jesteście nadzieją Kościoła i świata - wy jesteście moją nadzieją". Te słowa wciąż bywają przypominane. Młodzi i Kościół... Podsumowując - mówił Ojciec Święty - pragnę powiedzieć, że młodzi szukają Boga, szukają sensu życia, szukają ostatecznych odpowiedzi: ,,co mam czynić, aby osiągnąć Życie wieczne?”' (Łk 10, 25). W tym szukaniu młodzi nie mogą nie spotkać się z Kościołem. I Kościól też nie może nie spotkać się z młodymi. Trzeba tylko, ażeby Kościół miał dogłębne zrozumienie tego, czym jest młodość, jakie jest znaczenie młodości dla każdego człowieka. Trzeba także, ażeby młodzi rozpoznali Kościół, ażeby dostrzegli w nim Chrystusa, który idzie poprzez wieki z każdym pokoleniem, z każdym człowiekiem, idzie jako Przyjaciel. Ważny jest ten dzień w życiu, w którym młody człowiek przekona się, ze to jest jedyny Przyjaciel, który nie zawodzi, na którego można zawsze liczyćc ${ }^{16}$.

Spotkania te, przeżywane przez młodzież w duchu wiary pod przewodnictwem Ojca Świętego, są okazją do przemyślenia przez młodych ludzi prawd dotyczących ich miejsca w Kościele i w świecie: Światowe Dni i Spotkania Młodzieży to opatrznościowe chwile refleksji, które pozwalają młodym zastanowić się nad ich najgłębszymi pragnieniami, umocnić świadomość przynależności do Kościoła, a także wyznawać, z coraz większą radością i odwagą, wspólną wiarę w Chrystusa ukrzyżowanego i zmartwychwstałego (Orędzie na VIII ŚDM, 1993, L'Osservatore Romano, 10/1992).

Ojciec Święty Jan Paweł II przyznaje, że te spotkania z młodzieżą są okazją do wielu wzruszeń: Podczas niezapomnianych spotkań światowych często doznawałem wzruszenia na widok spontanicznej radości i miłości młodych do Boga i do Kościoła. Przynosili oni ze soba świadectwa o cierpieniu dla Ewangelii, o przeszkodach na pozór nieprzezwyciężonych, a pokonanych z Boża pomocą; mówili o niepokoju, jakiego doznaja wobec świata targanego przez rozpacz, cynizm i konflikty. Po każdym z tych spotkań żywiej odczuwałem potrzebę chwalenia Boga, który objawia młodym

${ }_{15}$ Jan Paweł II, List do kard. E. F. Pironio, art. cyt. , s. 4, p. 1.

16 Tenże, Przekroczyć próg nadziei, dz. cyt., s. 105. 
ks. bp Henryk Tomasik

tajemnice swojego Królestwa (por. Mt 11, 25) - wyznaje Ojciec Święty w Liście do Kardynała E. Pironio ${ }^{17}$.

Te uroczyste spotkania mają pomóc młodzieży w przyjmowaniu Bożych darów: Światowy Dzień Młodzieży ma więc przygotować nas wszystkich na przyjęcie daru Bożej miłości, która nas kształtuje i zbawia (Orędzie na II ŚDM, Buenos Aires, 1987, L’Osservatore Romano, 11-12/1986). Światowy Dzień Młodzieży jest ogromną szansą duszpasterską. Jest okazją do uaktywnienia kapłanów, młodzieży, wspólnot parafialnych oraz poszczególnych ruchów i stowarzyszeń. Zarówno wydarzenie Światowych Dni Młodzieży jak i przygotowanie duchowe na ich przeżywanie pozwala na doświadczenie nowego (młodego) Kościoła, daje możliwość odnowienia życia wspólnotowego w parafiach i ruchach, dzielenia się świadectwem wiary w małych grupach, pobudza ducha ofiary oraz zachęca do podejmowania wolontariatu. Te wyzwania stają także przed organizatorami najbliższych Światowych Dni Młodzieży, jakie odbędą się w Krakowie.

\section{Przygotowanie duchowe do Światowych Dni Młodzieży - Kraków 2016.}

W Orędzie na V ŚDM, 1990, Św. Jan Paweł II napisał: Światowy Dzień jest nie tylko świętem, ale także poważnym duchowym zadaniem. Aby był on owocny, potrzebne jest przygotowanie się doń pod kierunkiem pasterzy w diecezjach i w parafiach, w stowarzyszeniach, ruchach i kościelnych wspólnotach młodzieżowych. Starajcie się lepiej poznać Kościól, jego naturę, jego historię trwającą już dwa tysiące lat, a także jego życie dzisiaj ${ }^{18}$.

Rada ds. Duszpasterstwa Młodzieży oraz Krajowe Biuro Organizacyjne, w porozumieniu z Księdzem Kardynałem Dziwiszem oraz Komitetem Organizacyjnym ŚDM w Krakowie, podejmuje następujące zadania:

1. Przygotowanie propozycji programu duchowego przygotowania do ŚDM.

2. Przygotowanie materiałów duszpasterskich potrzebnych do dobrego przeżywania pielgrzymki Krzyża ŚDM.

3. Przygotowanie Pielgrzymki Krzyża ŚDM.

4. Przygotowanie propozycji zorganizowania „Dni w Diecezjach”.

Propozycje to są oparte na programie duszpasterskim Kościoła w Polsce oraz na Orędziach Ojca Świętego na kolejne Światowe Dni Młodzieży. Poszczególne lata przygotowań poświęcone będą następującym tematom:

a) Słowo (kerygmat) - rok 2013/2014

Błogosławieni ubodzy $w$ duchu, albowiem do nich należy królestwo niebieskie (Mt 5, 3);

b) Sakramenty (liturgia) - rok 2014/2015

17 Tenże, List do kard. E. F. Pironio, art. cyt., s. 4, p. 4.

18 Tenże, Orędzie na V ŚDM, 1990, za: L’OsRomPol 10-11(1989). 
Błogosławieni czystego serca, albowiem oni Boga oglądać będa (Mt 5, 8);

c) Caritas (diakonia) - 2015/2016

Błogosławieni miłosierni, albowiem oni miłosierdzia dostąpia (Mt 5, 7).

W pierwszym roku program bazuje na Słowie Bożym, które prowadzi człowieka do wiary w Jezusa, Syna Bożego. Punktem wyjścia spotkań miesięcznych jest jednak sytuacja egzystencjalna młodego człowieka, której interpretacja zostaje oświecona w świetle Słowa Bożego.

Materiały przygotowane na rok 2013/2014: Cz@t ze Słowem!, na każdy miesiąc zawierają wprowadzenie, konspekt spotkania w grupie, medytacje biblijne do indywidualnego wykorzystania, video komentarze do niedzielnych Ewangelii oraz propozycję wspólnotowej celebracji. Konspekty pracy w grupach oparte są na metodzie ewangelicznej rewizji życia: widzieć, ocenić, działać. Materiały te są umieszczone na stronach internetowych oraz wydane w pozycji książkowej.

Aktualnie zespół kapłanów i młodzieży przygotowuje materiały duszpasterskie dotyczące pielgrzymki Krzyża oraz programu duchowego na rok duszpasterski 2014/15. Zauważamy pojawianie się wielu cennych inicjatyw, pojawiających się w różnych diecezjach, dotyczących organizowania spotkań młodzieży, których celem jest przygotowanie do ŚDM Kraków - 2016. Niezwykle cenne jest tworzenie diecezjalnych i parafialnych „centrów ŚDM”. Modlitwa w intencji ŚDM, realizowanie programu duchowego przygotowania do ŚDM, podejmowanie inicjatyw duszpasterskich oraz przygotowywanie woluntariuszy dla ŚDM - to cenny wkład w przygotowanie do ŚDM - Kraków 2016.

Światowe Dni Młodzieżą są także ogromną szansą promocji Polski: polskiej kultury i historii, polskich tradycji duchowych i ważnych ośrodków kultu religijnego (Jasna Góra, Kraków - Łagiewniki, Niepokalanów i inne), polskich świętych oraz współczesnych wspólnot religijnych. Dlatego bardzo ważne będzie przyjęcie gości z całego świata w naszych diecezjach w dniach 20 - 25 lipca 2016 roku. Opiekunowie grup przyjeżdżających do Polski będą wybrać diecezję, do której pragną przyjechać w dniach poprzedzających krakowskie spotkanie. Konieczne jest zatem umieszczanie na stronach internetowych naszych diecezji ważnych informacji o Diecezji. Informacje te powinny pojawiać się w obcych językach. Ułatwi to naszym potencjalnych gościom dokonanie wyboru diecezji. Wiele z tych rzeczy udało się już zrobić, ale wciąż jest wiele pracy do wykonania, aby Światowe Dni Młodzieży w Krakowie mogły stać się czymś więcej, niż tylko wielkim festynem religijnym. Musimy dołożyć wszelkich wysiłków, aby były na tyle silnym doświadczeniem spotkania młodych ludzi z Chrystusem i Kościołem, które pozwoli im odpowiedzieć z wiara na Boże zaproszenia do pójścia z Nim. Wiele będzie zależeć od naszej pracy duchowej i od otwarcia na znaki czasu, czego także uczył nas przy okazji Światowych Dni Młodzieży św. Jan Paweł II. 
ks. bp Henryk Tomasik

\section{Streszczenie}

Inspiracją Światowych Dni Młodzieży były spotkania Jana Pawła II z młodymi ludźmi. Papież-Polak chciał, by w ten sposób młodzież wychodziła na spotkanie Bogu, który wszedł w dzieje człowieka. Dość szybko w inicjatywie dało się dostrzec cztery zasadnicze dynamizmy, na których do dziś opierają się spotkania. Te dynamizmy to chrystocentryzm, entuzjazm, kontemplacja krzyża i afirmacja młodości. Dzięki nim Światowe Dni Młodzieży nie ograniczają się do jednorazowej akcji, ale stanowią zaplanowaną działalność o charakterze katechetycznym. Domagają się przy tym rzetelnego przygotowania. Takie przygotowanie zostało już podjęte w Krakowie, dokąd przyjedzie młodzież z całego świata w roku 2016. Niezależnie od już opracowanych materiałów duszpasterskich i katechetycznych, nie można ustać w wysiłkach na rzecz Światowych Dni Młodzieży w Polsce, aby stały się one czymś więcej niż tylko festynem religijnym.

Słowa kluczowe: katecheza, wymiar katechetyczny, katecheza a Światowe Dni Młodzieży;

\section{WORLD YOUTH DAY AS THE CATECHETICAL EVENT Summary}

John Paul II's meetings with young people were an inspiration of World Youth Day. He wanted to encourage young people to meet God who entered into the history of the man. It was quite fast possible to behold the four fundamental dynamisms into the initiative on which present day meetings base. These dynamisms are christocentrism, enthusiasm, the contemplation of the cross and the affirmation of the youth. Thanks to them, World Youth Day does not confine to the one-time action, but it forms a planned activity of religious nature. In addition, it demands solid arrangements. Such a preparation was already taken in Cracow, where the young from the entire world will arrive in 2016. Despite the pastoral and catechetical materials that have been already drawn up, we cannot stand still in efforts for World Youth Day in Poland so that it becomes something more than a religious feast.

Keywords: World Youth Day, the catechesis, the catechetical dimension, the catechesis and World Youth Day. 